\title{
KAJIAN POLA PERMUKIMAN KHAS KAMPUNG LENGKONG ULAMA, SERPONG, BANTEN
}

\author{
KHAMDEVI, Muhammar \\ Email: arch_fiqh@yahoo.com
}

\begin{abstract}
ABSTRAK
Siapa yang tahu tentang Kampung Lengkong Ulama, Serpong? Mungkin dikenal oleh "kaum bersarung" saja, karena bergaung hanya di media-media agama. Tahun 1983, muncullah buku sejarah kampung ini karangan sekaligus termasuk terjemahan dari naskah kuno kampung ini oleh tokoh setempat; Ustadz Mukri Mian, namun tidak dipenerbitkan. Pada tahun 2009, hadir satu buku pencerah karangan arkeolog Indonesia; alm. Uka Tjandrasasmita. Hingga kini, baru beliaulah orang pertama yang meneliti kampung ini dari sudut pandang arkeologi, dengan kajian terhadap naskah dan peninggalan berupa makam. Namun beliau tidak menyebutkan tentang pola kampung ini, sebagaimana Ustadz Mukri Mian gambarkan dalam bukunya, bahwa posisi bangunan-bangunannya mengikuti posisi arah kiblat. Apakah pola permukiman Kampung Lengkong Ulama mengikuti posisi arah kiblat? Penelitian ini adalah penelitian baru yang bertujuan untuk mengkaji dan mengetahui pola kampung ini dan bagaimana proses terbentuknya. Penelitian ini menggunakan metode kualitatif dari sudut pandang arsitektur. Dari hasil penelitian dapat disimpulkan, bahwa pola Kampung Lengkong Ulama mengikuti posisi arah kiblat dan secara unik terletak pada bibir sungai yang juga mengikuti posisi arah kiblat. Selain itu, penempatan makam pendiri kampung ini di atas bukit memiliki benang merah dengan kebiasaan yang terjadi pada masyarakat dan kerajaan-kerajaan jawa pada umumnya mengenai dunia dan akhirat.
\end{abstract}

Kata kunci: Kampung bersejarah, konservasi, desa kota.

\begin{abstract}
Who knows about Kampong Lengkong Ulama, Serpong? Perhaps it has been known by "the sarong people", because it echoed only in the religious media. In 1983, there was a history book about this village, included essays and translations from ancient texts, written by local leaders; Ustadz Mukri Mian, without published. In 2009, there was a book written by Indonesian archaeologist; Uka Tjandrasasmita. Until now, he is the only person who researches about this village from archaeology perspective. He did not mention about the typical pattern of this village, as Ustadz Mukri Mian described in his book, that the position of the buildings follows the Qibla. Is the settlement pattern of Kampong Lengkong Ulama follows the Qibla? This paper is a new research to study the pattern of this village. This study uses qualitative method from architecture perspective. The research conclusion is that the pattern of Kampong Lengkong Ulama really follows the Qibla direction and situated by the river that also follows the Qibla. In addition, the placement of the tomb of the founder of this village on the hill has the same concept with the general concept in Javanese community and kingdoms about the world and the hereafter.
\end{abstract}

Keywords: Historic village, conservation, rural urban.

\section{PENDAHULUAN}

Selain dikenal sebagai Kampung Lengkong Kyai, seperti yang tertera pada signage yang saya temui di sana, kampung ini juga dikenal dengan banyak nama, seperti; Lengkong Sumedang atau Lengkong Ulama (Septayuda, 2011) dan bahkan Lengkong Alit atau Lengkong Kecil (Mukri, 1983). Bahkan pada peta topografi hanya disebut dengan Lengkong saja (Tjandrasasmita, 2009). Lain halnya yang disebutkan di majalah Media Dakwah, yakni disebut sebagai Lengkong Kulon (Dakwah, 1992). Kata Lengkong ini diambil dari asal pendiri kampung ini, Raden Arya Wangsa Di Kara, di Sumedang (Mian, 1983). Raden Wangsa Di Kara, atau Raden
Arya Wangsakara adalah seorang ulama dan dapat dipastikan adalah Pangeran Arya Wiraraja II yang berasal dari Sumedang, yang pindah dari Sumedang ke Banten untuk menghindari dari tekanan Kerajaan Mataram dan dari Pemberontakan Dipati Ukur (Tjandrasasmita, 2009). Selain itu kata Lengkong ini juga menunjukkan bahwa lokasi kampung ini berada pada sebuah lingkung air; sungai (Mian, 1983).

Kampung Lengkong Ulama terletak di jantung kota Serpong, berdampingan dengan pengembangan kota Bumi Serpong Damai (BSD). Eksistensinya semakin dikhawatirkan, karena makin lama kampungkampung disekitarnya mulai pudar tergantikan dengan perumahan dan fungsi baru. Apalagi kekhawatiran itu makin bertambah, sejak salah satu jembatan peng- 
hubung wilayah barat dan timur Sungai Cisadane mulai terealisasikan, Juli 2010 (Seno, 2011), yang sudah satu dekade tertunda akibat ketidak setujuan warga setempat. Tentu saja hal ini akan memberikan dampak yang besar bagi eksistensi kampung ini, yang sejak lama tertutup dan tersembunyi secara alamiah, akan terekspos dengan perubahan yang cenderung akan ekstrim.

Padahal berdasarkan analisis sejarah, arkeologis, tradisi setempat, bahkan dari segi geografis serta lingkungannya, yang dilakukan oleh Bapak Arkeolog Islam Indonesia, Uka Tjandrasasmita, Kampung Lengkong Sumedang atau Lengkong Ulama, merupakan kampung bersejarah atau situs bersejarah (historical site) yang perlu diperhatikan kelestariannya (Tjandrasasmita, 2009).

Sejak berdirinya kota Tangerang Selatan, Kabupaten Tangerang tidak memiliki makam pahlawan, karena Makam Seribu Pahlawan beralih ke Kota Tangerang Selatan. Sehingga Pemerintah Kabupaten Tangerang merenovasi komplek makam Kampung Lengkong Ulama sebagai Makam Pahlawan Kabupaten Tangerang, yang diresmikan pada tanggal 17 Agustus 2012 (Bharatanews, 2012).

Kampung Lengkong Ulama telah dilalui oleh banyak peristiwa sejarah, terutama mewarnai sejarah Tangerang. Dari semenjak zaman kerajaan Mataram, lalu perjuangan Sultan Ageng Tirtayasa terhadap VOC Belanda (Tjandrasasmita, 2009), hingga juga pada masa kemerdekaan; terutama menjadi salah satu basis Masyumi (Mian, 1983) dan juga menjadi area pertempuran Mayor Daan Mogot, yang dikenal sebagai "Pertempuran Lengkong" (Seno, 2011). Itu dikarenakan kampung ini terletak secara strategis di Sungai Cisadane untuk syiar Islam dan perdagangan.

Dari dulu hingga sekarang kampung ini telah mencetak banyak ulama. Tak heran dalam satu kampung terdapat banyak Kyai yang memiliki pengikut yang tersebar di wilayah Tangerang pada saat ini (Mian, 2001). Selain itu para ulama dan santrinya memiliki keterampilan dalam kaligrafi yang diakui hingga dunia internasional (Septayuda, 2011).

Sayangnya hingga kini, peneliti yang mengkaji kampung ini barulah seorang, yakni Uka Tjandrasasmita. Beliau menggali kesejarahan kampung ini dengan pendekatan arkeologi, yakni dari objek naskah dan peninggalan makam. Menurut beliau berdasar babad-babad jawa terutama Babad Cirebon, pendiri kampung ini, Raden Arya Wangsakara dapat dipastikan adalah Pangeran Arya Wiraraja II yang berasal dari Sumedang, yang memiliki benang merah dengan Kesultanan Cirebon.

Data arkeologis kampung ini adalah makam Raden Arya Wangsakara yang bertipe arkaik (Abad
17) dan letaknya berada di atas bukit yang mengingatkan pada model makam para Sunan dan Sultan di Jawa, makam Kyai Mustaqim yang bertipe antefik (abad 18-19), bekas rumah istri kedua Raden Arya Wangsakara dan Masjid Raden Arya Wangsakara yang sekarang sudah dirombak habis menjadi lebih modern.

Sebenarnya ada bukti tertulis dari kampung ini, naskah asli yang pernah disimpan oleh almarhum Kyai Muchtar dan Bapak Yasin, yang ditulis dalam huruf pegon pada kertas daluwang dengan tinta cina. Naskah asli tersebut pernah dipinjamkan kepada dosen dan beberapa mahasiswa yang melakukan Kuliah Kerja Nyata. Naskah ini tidak pernah dikembalikan, namun arkeolog; Uka Tjandrasasmita, memastikan bahwa naskah itu sudah pasti asli, dan patut ditelusuri ke mana sekarang naskah itu berada. (Tjandrasasmita, 2009).

Untungnya naskah tersebut sempat diterjemahkan ke dalam Bahasa Indonesia dalam sebuah buku yang diproduksi untuk kalangan terbatas oleh Ustadz Mukri Mian pada tahun 1983. Uka Tjandrasasmita memastikan bahwa data-data dalam buku tersebut dapat diabsahkan, dengan berdasarkan kepada gambaran fisik naskah aslinya (Tjandrasasmita, 2009).

Dalam buku tersebut tercantum tentang pola kampung yang mengikuti arah kiblat. Hal ini diperkuat lagi dengan wawancara terhadap informan kunci, yakni Ustadz Mukri Mian, dan terhadap informan lainnya, yakni para Kyai Kampung Lengkong Ulama. Karena belum ada yang meneliti tentang hal ini, termasuk Bapak Arkeologi Islam Indonesia, Uka Tjandrasasmita, sehingga lokasi dan kasus kajian ini menjadi penting dan menarik untuk diadakan penelitian terhadap pola kampung ini secara ilmiah.

Apakah pola Kampung Lengkong Ulama mengikuti arah kiblat? Makalah ini mencoba membahas pola Kampung Lengkong Ulama dari perspektif arsitektur. Dengan kajian ini, diharapkan bertambah lagi penelitian baru mengenai kampung ini dan membuka peluang untuk penelitian-penelitian selanjutnya.

\section{METODE PENELITIAN}

Penelitian ini menggunakan metode kualitatif dengan pendekatan analisis deskriptif. Data primer dikumpulkan secara empirik melalui pengamatan lapangan, pengambilan foto dan pembuatan sketsa, serta wawancara yang mendalam untuk menggali informasi dari responden sebagai informan kunci. Informan kunci dipilih berdasarkan otoritas penuh yang diberikan warga sebagai juru bicara mengenai 
seluk beluk kampungnya. Sedangkan informan yang lain digunakan sebagai bahan pembanding dan pemeriksaan.

Data sekunder diperoleh dari referensi pustaka, peta-peta dan dokumen-dokumen pendukung dan pembanding yang relevan untuk memperkuat argumentasi. Karena baru satu peneliti yang mengkaji kampung ini, maka data-data studi kasus yang mirip sangat diperlukan sebagai data pembanding.

Data-data yang telah dikumpulkan dari segala sumber tersebut diperiksa, dipilah, diolah lalu dianalisis. Analisis dilakukan pertama-tama terhadap kondisi eksisting, lalu diuji dengan teori pembentuk kota Kevin Lynch untuk mengidentifikasi pembentuk citra kawasan dan selanjutnya dikaji lagi dengan teori figure ground untuk mengidentifikasi pola tata ruang dan hubungan antar massa atau ruang (Zahnd, 1999).

\section{HASIL DAN PEMBAHASAN}

\section{Proses Terbentuknya Kampung}

Setelah berpindah-pindah beberapa kali, akibat ancaman dari VOC, akhirnya Raden Arya Wangsakara mendapatkan lokasi yang tepat. Lokasi kampung ini strategis tersembunyi dan terlindungi oleh alam (hutan bambu) dan dilingkungi Sungai Cisadane dan kali kecil. Dan uniknya, penentuan lokasi yang dilakukan beliau berdasarkan pemilihan bagian alur Sungai Cisadane yang secara kebetulan menghadap kiblat. Hal ini mempengaruhi posisi bangunan rumahrumah santri yang berupa gubug panggung yang mengikuti posisi kiblat, serta bagian memanjang rumah tersebut menghadap sungai dan bukit. Bangunan yang pertama kali dibangun adalah masjid yang menjorok ke dekat sungai, lalu gubug-gubug para santri (Mian, 1983).

Hal ini serupa dengan proses terbentuknya pondok pesantren tradisional pada umumnya. Suatu pondok pesantren berawal dari adanya seorang kyai di suatu tempat, kemudian datang santri yang ingin belajar agama kepadanya. Setelah semakin hari semakin banyak santri yang datang, timbullah inisiatif untuk mendirikan pondok atau asrama di samping rumah kyai. Para santri selanjutnya memopulerkan keberadaan pondok pesantren tersebut, contohnya seperti pada pondok-pondok yang timbul pada zaman Walisongo (Hielmy, 2000).

Akhirnya, lambat laun beberapa santri ada yang bermukim dan berkeluarga di sana. Gubug-gubug santri yang bertipe panggung dengan atap julang ngapak berubah menjadi rumah-rumah hingga membentuk sebuah permukiman kampung (Mian, 1983).
Ketika wafatnya Raden Arya Wangsakara, beliau dimakamkan di bukit yang bersebelahan dengan kampung. Penempatan makam ini mirip dengan makam-makan sultan maupun sunan di masyarakat jawa pada umumnya (Tjandrasasmita, 2009).

Penempatan makam islam di jawa merupakan akulturasi dengan agama-agama sebelumnya, seperti: animisme, hindu dan budha. Penempatan makam biasanya diletakkan; pertama, di tempat yang lebih tinggi (gunung atau bukit). Biasanya untuk para raja. Contoh: Komplek Makam Sunan Gunung Jati dan Makam raja-raja Mataram di Bukit Imogiri. Kedua, dekat dengan masjid. Biasanya para wali dan ulama. Contoh: Masjid Demak, Kadilangu dan Sendang Duwur (Mustopo dkk., 2003).

Bagi masyarakat jawa, gunung atau bukit menyimbolkan status yang tinggi sekaligus merupakan upaya mendekatkan diri dengan Yang Maha Kuasa. Orang Jawa percaya gunung adalah tempat sakral dan biasanya didiami oleh mahluk halus, rohroh leluhur atau dewa. Gunung atau bukit melambangkan hubungan antara dunia manusia atau bumi dan akhirat atau kahyangan (Walsh, 2000). Keberadaan masjid pada proses permulaan terbentuknya kampung yang dibangun oleh pendiri kampung hingga makam pendiri di bukit menunjukkan sebuah hubungan kesatuan timeline cerita sejarah dan menggambarkan hubungan dunia dan akhirat tersebut.

\section{Eksisting Kampung}

Dilihat dari lingkungan alamiah eksistingnya, posisi alur Sungai Cisadane yang menjadi lokasi Kampung Lengkong Ulama memang terlihat secara kebetulan sesuai dengan arah kiblat, yakni 25 derajat dari barat ke utara (BADILAG, 2007). Dari data vegetasi dan topografi, kampung ini benar-benar tersembunyi dan tertutup dari lingkungan lainnya, sehingga dapat menjadi tempat untuk berlindung dari tekanan VOC dan juga melaksanakan pengajaran Islam dengan lebih nyaman dan aman. Hal ini menunjukkan pemilihan lokasi oleh Raden Arya Wangsakara memang sudah diperhitungkan dengan matang.

Selain fungsi hunian, terdapat fasilitas-fasilitas umum berupa; masjid, musholla, majelis ta'lim, makam, pesantren dan madrasah. Objek-objek sejarah yang ada di kampung ini, antara lain: Masjid $\mathrm{Al}$ Muttaqin, Makam Raden Arya Wangsakara, Makam Kyai Mustaqim, Makam Kyai Azhari, Musholla Azhari dan Rumah-rumah kuno yang bertipe mirip rumah Betawi atau Banten. 


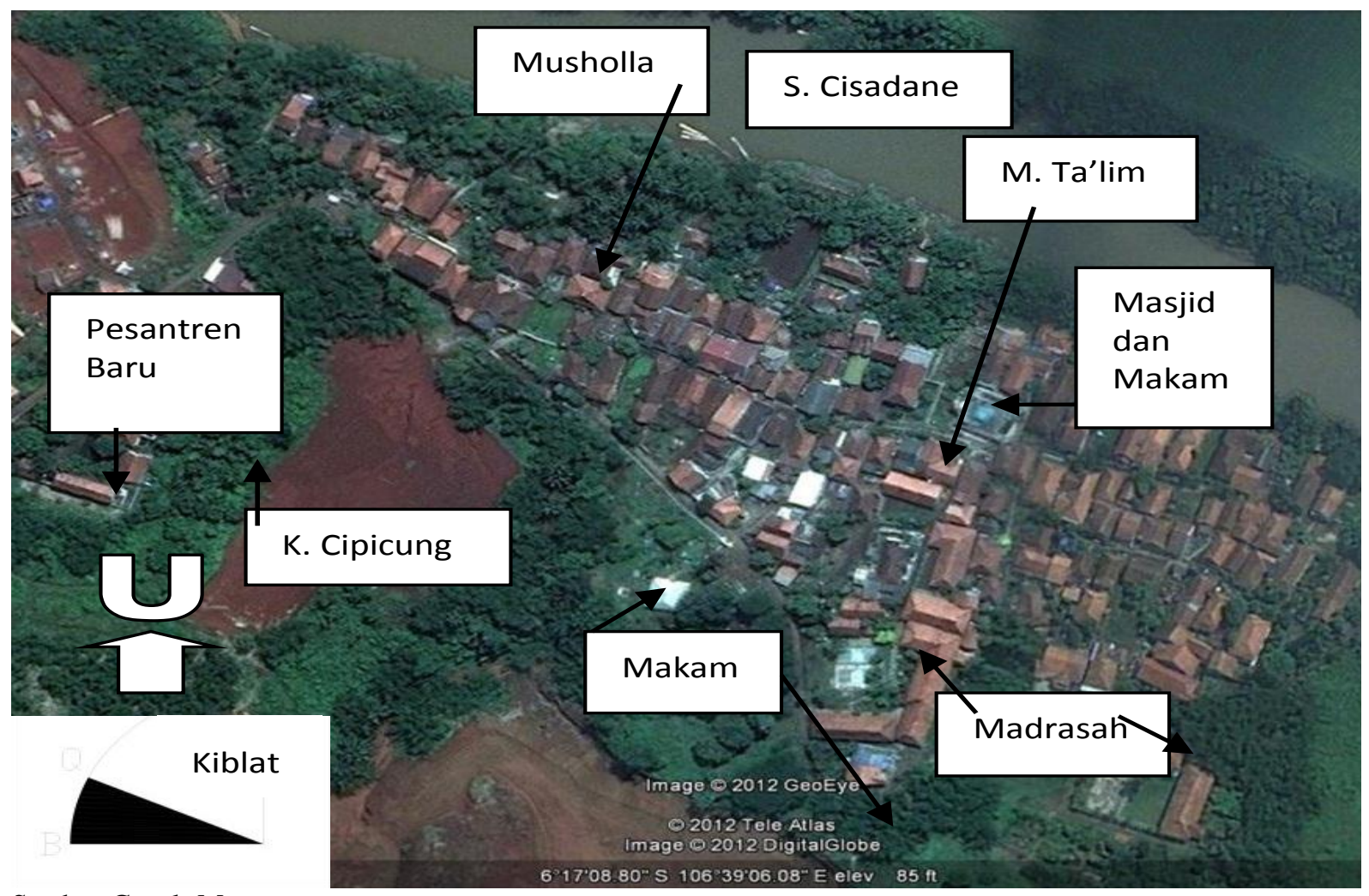

Sumber: Google Map

Gambar 1. Peta Satelit Kampung Lengkong Ulama, Serpong, Banten

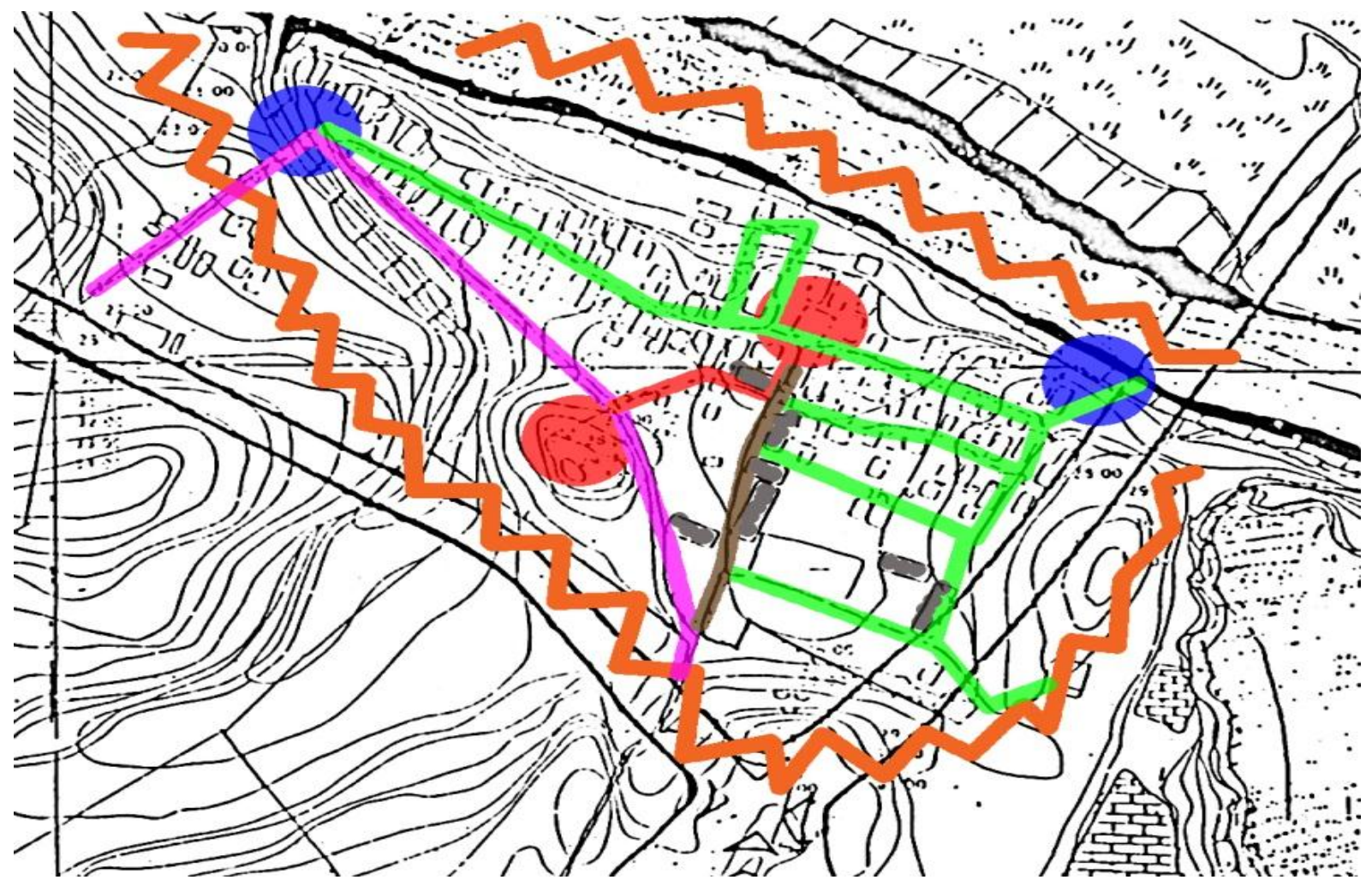

Sumber: Jarot dan Purwono, Geografi UI

Gambar 2. Peta Kampung Lengkong Ulama, Serpong, Banten 


\section{Elemen Pembentuk Kampung}

Pintu masuk ke lokasi kampung ini bisa melalui jalur sungai dengan ditandai dengan alat transportasi getek yang berada pada sisi timur kampung dan juga bisa melalui jalur darat yang berada pada sisi barat kampung ini, di mana pintu masuk ini ditandai dengan turunan yang curam, hutan yang lebat dan jembatan Kali Cipicung.

Sedangkan batas fisik kawasan kampung ini secara dominan dibatasi oleh elemen alamiah yang melingkungi kampung, seperti: sungai, hutan dan bukit. Namun selain batas fisik, kampung ini memiliki batas non fisik, berupa makam yang disakralkan. Batas non fisik sulit dibuktikan, karena berkaitan dengan keyakinan warga, tetapi dapat dirasakan, seperti: takut, angker, seram, hormat dan lain-lain (Nuryanto, 2007).

Landmark kawasan kampung ini adalah Masjid dan Makam. Jaringan jalannya juga terbentuk secara organik dengan pola grid-iron (papan catur), di mana pola jalan terjadi disebabkan bentukan dari permukiman. Pola jalan dan permukiman ini mirip dengan pola permukiman Kampung Kauman Surakarta (Setyaningsih, 2007).

\section{Struktur Kampung}

Kampung, dalam hal ini desa, adalah merupakan suatu hasil perpaduan antara kegiatan kelompok manusia dengan lingkungannya. Pola ruang desa, terutama di pulau Jawa, dapat dibedakan menjadi empat macam (Bintarto, 1983). Pertama, memusat; bentuk perdesaan ini terpencar menyendiri. Kedua, linier; bentuk perdesaan ini memanjang mengikuti jalur jalan raya, alur sungai atau garis pantai. Ketiga, terpencar; bentuk perdesaan yang terpencar cenderung menyendiri. Keempat, mengelilingi fasilitas; bentuk perdesaan mengelilingi fasilitas-fasilitas umum.

Dari analisis figure ground, dapat diketahui bahwa pola kampung ini memiliki pola linear dan terpusat ke Masjid. Namuin pola liniear ini justru tidak umum seperti pola desa yang ada di Indonesia umumnya. Seharusnya dengan kampung ini berada di sisi sungai, maka ia harus mengikuti pola alur sungainya. Namun ini tidak, justru ia menentang pola lingkungan alamiahnya.

Dari sinipun diketahui pula, bahwa pola-pola bangunan secara umum, selain Masjid, sepertinya memang mengikuti posisi kiblat, yakni 25 derajat dari arah barat ke utara (BADILAG, 2007), dengan sisi yang memanjang menghadap ke arah utara dan

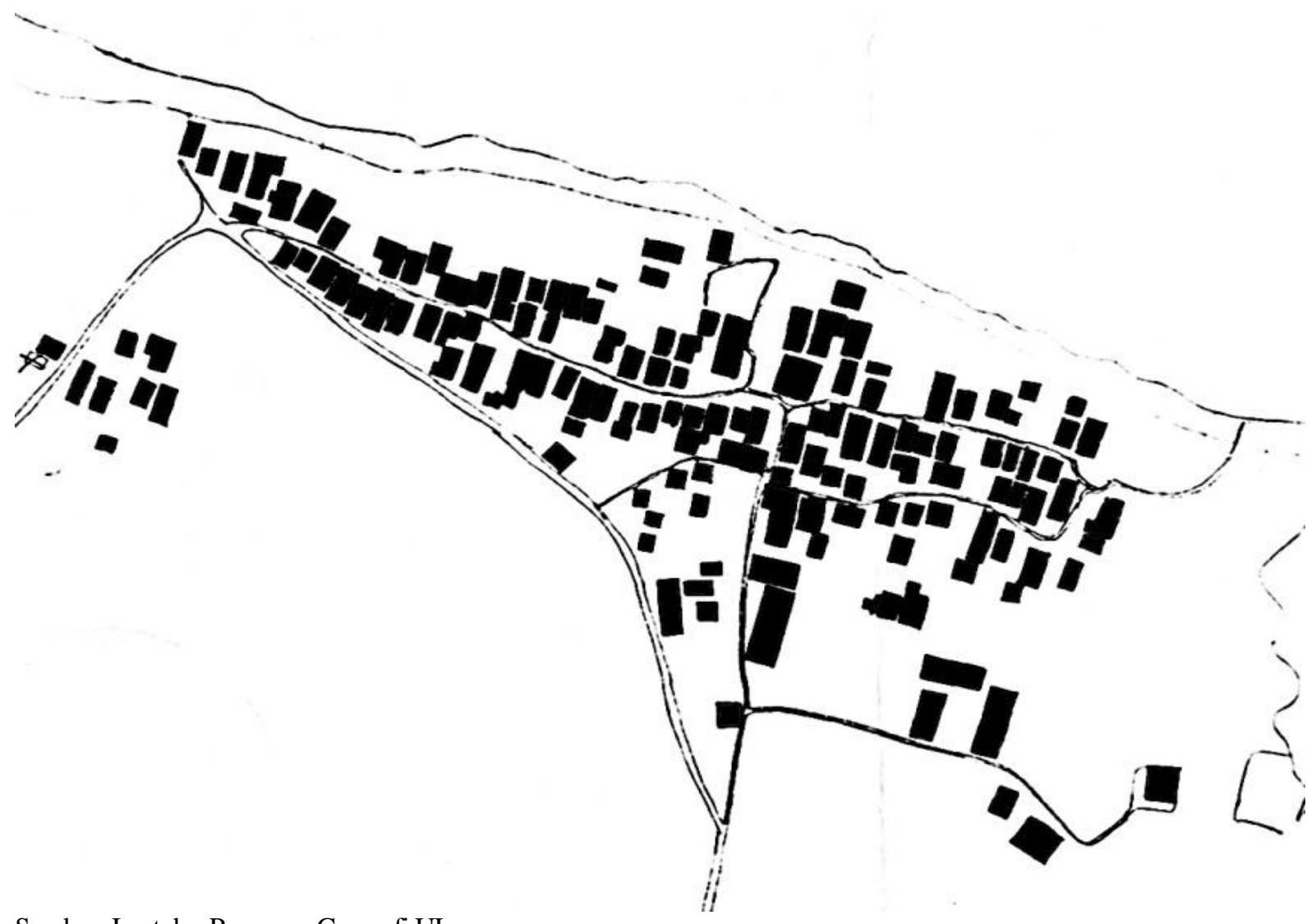

Sumber: Jarot dan Purwono, Geografi UI

Gambar 3. Peta Kampung Lengkong Ulama, Serpong, Banten 
selatan; sungai dan bukit (makam). Hal ini bisa disebabkan, bahwa pada mula berdirinya, kampung ini merupakan pesantren yang terdiri dari masjid dan pondok (gubug) santri. Dengan berdirinya masjid, posisi pondok dan bangunan pendukung lainnya pun praktis mengikuti posisi masjid. Maka dengan makin berkembangnya pesantren dan santri-santrinya menetap, maka yang tadinya hanyalah sebuah pesantren, justru berkembang menjadi sebuah kampung baru.

Dari analisis ini juga terlihat, bahwa semakin keluar, ada beberapa posisi bangunan mulai tidak mengikuti pola sebelumnya, seakan terjadi inkonsistensi. Menurut penuturan Ustadz Mukri Mian (2001), bahwa pola ini tidaklah mengikat dan tergantung bentuk kavling yang dimiliki. Walau begitu, ini justru memudahkan dalam menentukan mana yang merupakan kampung bagian yang lama dan mana yang baru.

\section{KESIMPULAN}

Dari riset ini, maka disimpulkan bahwa pola kampung Lengkong Ulama adalah linier dan mengikuti posisi arah kiblat, dimana bagian memanjang bangunan, terutama hunian, menghadap utara dan selatan; sungai dan bukit. Kampung ini dilingkungi oleh objek alamiah, berupa; sungai, kali, hutan bambu dan bukit, sehingga kampung ini tertutup dari wilayah sekitarnya. Akses masuk ke kampung ada di sisi barat (darat) dan pada sisi timur (air/ getek).

Dari hasil analisis ini juga diketahui bahwa kampung lama berada pada lapis pertama yang dekat dengan bibir Sungai Cisadane. Pola dan posisi bangunan kampung ini berpola linear dan terpusat, dimana hampir $100 \%$ mengikuti posisi arah kiblat. Bagian yang memanjang dari bangunannya menghadap bukit dan sungai. Bukit - makam dan sungai masjid merepresentasikan hubungan timeline sejarah dan juga hubungan analogi dunia-akhirat dalam kaitannya dengan Ketuhanan yang berlaku umum pada masyarakat jawa.

Dengan potensi yang begitu beragam ini, baik secara fisik maupun budaya, kampung ini sangat cocok sekali menjadi kawasan wisata religi dan budaya, seperti yang juga diusulkan oleh Uka Tjandrasasmita, yang menyatakan bahwa kampung ni adalah kampung bersejarah. Sehingga Pemerintah Kabupaten Tangerang sebaiknya tidak hanya menetapkannya makam pendiri kampung sebagai Makam Pahlawan Kabupaten Tangerang saja, tapi Kapung Lengkong Ulama juga sebagai kampung bersejarah yang memiliki objek wisata. Potensi wisata yang mungkin bisa diangkat adalah wisata ziarah, wisata santri (belajar ilmu agama), wisata kaligrafi, wisata alam dan wisata sejarah. Namun perlu dilakukan upaya penataan untuk merevitalisasi kampung ini. Ini menjadi bahan riset berikut peneliti, selain melengkapi riset saat ini dengan data segar.

\section{DAFTAR PUSTAKA}

Badilag (2007). Daftar Arah Kiblat Kota-Kota di Indonesia. Direktorat Jenderal Badan Peradilan Agama, Mahkamah Agung Republik Indonesia. http://www.badilag.net/data/hisabrukyat/Daftar Koord. Geo\&Arah Kiblat.pdf

Bintarto, R. (1983). Interaksi Desa-Kota Dan Permasalahannya. Yogyakarta: Ghalia I Indonesia.

Hielmy, Irfan (2000). Wacana Islam. Ciamis: Pusat Informasi Pesantren.

Mian, M. (1983). Sejarah Kampung Lengkong. Lengkong: tanpa penerbit.

Mustopo, Habib (2003). Sejarah dan Budaya: Dari Masa Kuno Sampai Kontemporer. Malang: UM Press.

Nuryanto \& I. Machpudin (2007). Kajian Pola Kampung dan Rumah Tinggal: Warga Kasepuhan Kesatuan Adat Banten Kidul di Sukabumi Selatan-Jawa Barat. Artikel Hasil Penelitian Arsitektur Tradisional Sunda. Bandung: Universitas Pendidikan Indonesia.

N.n. (1992). Lengkong Kulon: Kampung Ulama yang Nyaris Punah. Jakarta: Media Dakwah.

N.n. (2012). Makam Pendiri Tangerang Gantikan Taman Makam Pahlawan Seribu.

Bharatanews, 2012. (http://bharatanews.com/berita-1717makam-pendiri-tangerang-gantikan-taman-makanpahlawan-seribu.html)

Seno (2011). Kelak, Makam Pahlawan Kab. Tangerang Ada di Lengkong Kulon. Jakarta: Kompasiana.com. (http://sejarah.kompasiana.com/2011/ 07/24/kelak-makam-pahlawan-kab-tangerangada-di-lengkong-kulon/).

Seno (2011). Lengkong Kulon, Desa yang Nyaris Hilang. Jakarta: Kompasiana.com. (http://sejarah. kompasiana.com/2011/07/24/lengkong-kulondesa-yang-nyaris-hilang/).

Septayuda, T. (2011). Jejak Arkeologis Penyebaran Agama Islam di Tangerang. Ponorogo: Majalah Gontor.

Setyaningsih, W. (2007). Potensi Spasial Fisik Kampung Kauman Surakarta sebagai Kawasan Budaya dan Religi. Gema Teknik-Nomor 2/Tahun X Juli 2007.

Tjandrasasmita, U. (2009). Arkeologi Islam Nusantara. Jakarta: Kepustakaan Populer Gramedia.

Walsh, D. (2000). Kepercayaan Masyarakat Jawa Terhadap Gunung. Thesis. http://www.acicis. murdoch.edu.au/hi/field_topics/dylan.html

Zahnd, M. (1999). Perancangan Kota Secara Terpadu. Yogyakarta: Kanisius. 